\title{
LETTER \\ Metals in quartz-hosted melt inclusions: Natural facts and experimental artifacts
}

VADIM S. KAMENETSKY* AND LEONID V. DANYUSHEVSKY

Centre for Ore Deposit Research and School of Earth Sciences, University of Tasmania, Hobart 7001, Australi

\begin{abstract}
Studies of melt inclusions trapped in magmatic phenocrysts can provide a new perspective on several key outstanding problems in the understanding of the genesis of orthomagmatic ore deposits, particularly with respect to the concentration of metals in parental magmas. The published data shows a mismatch between low and high abundances of $\mathrm{Cu}$ (and $\mathrm{Ag}$ ) in unheated and remelted melt inclusions, respectively. This experimental study investigates the possibility that quartz-hosted rhyolitic melt inclusions may change their composition during laboratory heating under different conditions. Exceptional volatility of $\mathrm{Cu}$ and $\mathrm{Ag}$ and inert behavior of other metals ( $\mathrm{Zn}, \mathrm{Pb}, \mathrm{Mo}, \mathrm{Sn}, \mathrm{W}$ ) and lithophile trace elements at high temperature $\left(850^{\circ} \mathrm{C}\right)$ is demonstrated. Heating experiments with melt inclusions require specific conditions that should take the high volatility of $\mathrm{Cu}$ and $\mathrm{Ag}$ into account. The open system behavior of $\mathrm{Cu}$ and $\mathrm{Ag}$ can also affect the composition of melt inclusions within the time frame between trapping and eruption
\end{abstract}

\section{INTRODUCTION}

Melt inclusions are small batches (usually $<50 \mu \mathrm{m}$ ) of magma incorporated inside crystallizing minerals, and as such they can provide invaluable information about physical parameters and chemical compositions of the magmatic environment (Roedder 1979). Melt temperature and composition, liquidus assemblage and liquid line of descent, pre-eruptive abundances of volatile and metallic elements, and many other variables are more and more constrained from melt inclusions in petrological and geochemical studies.

Reconstruction of originally trapped melt composition, including volatile and trace elements, is invariably hampered because most melt inclusions suffer post-entrapment modifications (Anderson 2003; Roedder 1979; Thomas 1994). Compositional changes to the melt inside inclusions are caused by crystallization on the inclusion walls, diffusion exchange with the host mineral and surrounding magma (Anderson 2003; Cottrell et al. 2002; Danyushevsky et al. 2000; Gaetani and Watson 2000; Qin et al. 1992; Tait 1992; Thomas 1994), and leakage (Anderson 2003; Davidson and Kamenetsky 2001; Frezzotti 2001; Nielsen et al. 1998; Skirius et al. 1990). The melt inside inclusions is rarely quenched to glass, being more often recrystallized, and thus heating of melt inclusions is commonly required to produce glass suitable for analysis (Danyushevsky et al. 2002; Lowenstern 1995; Skirius et al. 1990). Although heating of melt inclusions in the laboratory is often unable to fully reverse post-trapping changes, it aids in obtaining an accurate composition of the melt inside the inclusions.

Melt inclusion studies of magmatic abundances of metallic elements (e.g., $\mathrm{Cu}, \mathrm{Zn}, \mathrm{Pb}, \mathrm{Mo}, \mathrm{Ag}$, $\mathrm{Au}$, etc.) are aimed at understanding their behavior during crystallization and degassing, and the role of different silicate magmas in contributing to economic mineralization. The outstanding question in this instance is whether inherently metal-enriched (fertile) magmas exist in

\footnotetext{
*E-mail: Dima.Kamenetsky@utas.edu.au
}

nature and originate metal-bearing fluids, or whether occurrence of mineralization is governed by other factors. The analysis of unheated glass inclusions in quartz from several unmineralized felsic rocks yield low $\mathrm{Cu}$ abundances (Lowenstern 1993; Lowenstern et al. 1991), however, several studies of experimentally reheated melt inclusions from mineralized systems have demonstrated exceptionally high metal concentrations (Campos et al. 2002; Dietrich et al. 1999). For example, quartz-hosted homogenized melt inclusions from the Zaldivar porphyry-Cu deposit, Northern Chile, contained ore-grade concentrations of copper (up to $1.5 \mathrm{wt} \%$ ) (Campos et al. 2002). In another example, significant enrichment in copper (up to $0.7 \mathrm{wt} \%$ ) and silver (up to $329 \mathrm{ppm}$ ) in experimentally reheated and quenched melt inclusions in quartz from the Bolivian tin porphyry system (Dietrich et al. 1999) is in marked contrast with metal-poor compositions of natural glassy inclusions from the same suite.

The existing discrepancy in the results obtained from unheated and reheated inclusions of felsic melts in quartz warranted this study which tests (1) the possibility of metals being introduced into high-Si melt inclusions during experimental heating and (2) the existence of metal-rich magmas in nature.

\section{SAMPLES, EXPERIMENTAL AND ANALYTICAL SETUP}

The sample NZL 27b is from a rhyolitic dome within the Maroa Volcanic Center that belongs to the Taupo Volcanic Zone (TVZ), New Zealand. The TVZ is currently the largest active felsic system having produced $\sim 15 \times 10^{3} \mathrm{~km}^{3}$ of volcanic rock over 1.6 Ma (Wilson et al. 1995), dominated by compositionally uniform, metaluminous rhyolites. The rock is composed of phenocrysts of plagioclase, quartz, and minor hornblende and biotite, set in a vesicular glassy groundmass. The groundmass glass is a high-Si rhyolite (in wt\%: $\mathrm{SiO}_{2} 75, \mathrm{Al}_{2} \mathrm{O}_{3}$ 11.9, $\mathrm{Na}_{2} \mathrm{O}$ 3.7, $\mathrm{K}_{2} \mathrm{O} 4.3$ ) and has major and trace element composition similar to other TVZ rhyolite and orogenic rhyolite worldwide. Unlike many other TVZ samples, this rock has quartz-hosted melt inclusions quenched to glass, and thus, for the purpose of this study, the melt inclusions do not require homogenization and can be analyzed unheated.

The rock was gently crushed in a steel mortar, sieved, and several hundred quartz grains $(0.5-1 \mathrm{~mm})$ containing large melt inclusions $(>30 \mu \mathrm{m})$ were handpicked under a binocular microscope. The quartz fraction was subdivided onto five sets with roughly equal numbers of grains. The first set (A) was mounted in epoxy resin for analysis, and other sets were heated as described below in a muffle 
furnace in air, and quenched. Sets B and C were heated in ceramic crucibles at $850^{\circ} \mathrm{C}$ for 24 and $120 \mathrm{~h}$, respectively. Following heating, about half of the grains from set $\mathrm{B}$ were mixed with powdered $\mathrm{NaCl}$, wrapped in $0.05 \mathrm{~mm}$ platinum foil and heated again at the same conditions, making a new set $\mathrm{E}$. The grains from set D were wrapped in $0.05 \mathrm{~mm}$ platinum foil and placed in a ceramic crucible and heated at $850{ }^{\circ} \mathrm{C}$ for $24 \mathrm{~h}$. Set $\mathrm{F}$ is represented by quartz grains heated at the same conditions in the mixture with powdered $\mathrm{CuSO}_{4} \cdot 6 \mathrm{H}_{2} \mathrm{O}$. The chosen temperature of $850^{\circ} \mathrm{C}$ was deduced from preliminary experiments with individual melt inclusions in a Linkam TS 1500 heating stage in which fluid bubbles, appearing in the melt inclusions at the $\alpha-\beta$ quartz transition $\left(573{ }^{\circ} \mathrm{C}\right)$, dissolve completely at $820-850$ ${ }^{\circ} \mathrm{C}$ (homogenization). After experimental heating, quartz grains were mounted in epoxy mounts, ground, polished with a $0.3 \mu \mathrm{m}$ alumina powder, thoroughly cleaned in the ultrasonic bath and wiped with a methanol-moistened tissue.

Randomly selected inclusions from sets A and B, exposed at the surface of quartz, were analyzed for major elements using a Cameca SX-100 electron microprobe (University of Tasmania). The major element variations among 22 analyzed inclusions were found to be small $\left(\mathrm{SiO}_{2} 74.0 \pm 1.0 \mathrm{wt} \% ; \mathrm{Al}_{2} \mathrm{O}_{3} 11.0 \pm\right.$ $0.4 \mathrm{wt} \%$; total $94.3 \pm 1.3 \mathrm{wt} \%)$.

Trace element concentrations in melt inclusions were analyzed by LA-ICPMS at the University of Tasmania. This instrumentation comprises a New Wave Research UP213 Nd-YAG $(213 \mathrm{~nm})$ laser coupled to an Agilent 4500 quadrupole mass-spectrometer. For this study, analyses were performed in a He atmosphere by ablating 40-110 $\mu \mathrm{m}$-diameter spots at a rate of 5 shots/s using a laser power of $\sim 12$ $\mathrm{J} / \mathrm{cm}^{2}$. The instrument was optimized for sensitivity on mid- to high-mass isotopes (in the range 80-240 a.m.u.) and for minimal molecular oxide species (i.e., ${ }^{232} \mathrm{Th}^{16} \mathrm{O} /$ ${ }^{232} \mathrm{Th}<0.2 \%$ ) and doubly charged ion species (i.e., ${ }^{140} \mathrm{Ce}^{++} /{ }^{140} \mathrm{Ce}^{+}<0.3 \%$ ) production The low level of molecular oxide and doubly charged ion production precludes the need to correct any of the analyte signal intensities for interfering species. Each analysis involves sequential peak hopping through the mass spectrum, with the accumulation of $\sim 50-150$ replicate measurements of $\sim 20$ milliseconds duration (1-3 seconds total) for each of the 28 analyte isotopes. The analysis time for each sample was 50-90 seconds, comprising a 30 second measurement of background (laser off) and a 20-60 second analysis with laser on. Instrument calibration was performed by ablating the NIST612 glass standard. Data reduction was undertaken according to standard methods (Longerich et al. 1996) using the NIST612 glas as a primary reference material and $\mathrm{Al}\left(11 \mathrm{wt} \% \mathrm{Al}_{2} \mathrm{O}_{3}\right)$ as the internal standard. USGS BCR-2g glass was repeatedly analyzed throughout analytical sessions and was used as a secondary reference material. Quartz phenocrysts were analyzed under similar conditions, using a 110 micrometer beam and the 10 shots/s rate, and $\mathrm{Si}$ as the internal standard.

\section{RESULTS}

Heating of quartz grains under different conditions had no effect on the appearance of melt inclusions after quenching; they remained clear silicate glass, like in the unheated grains, sometimes with a small shrinkage bubble. Quartz grains from set $\mathrm{E}$ developed rounded or spherical shapes following reaction with $\mathrm{NaCl}$ added to this charge.

The average compositions of melt inclusions (in ppm) and compositional variability within each experimental set are summarized in Table 1. Melt inclusions from all sets have similar abundances of the analyzed trace elements but $\mathrm{Cu}$ and $\mathrm{Ag}$ (Table 1). Melt inclusions from a given set display a small range of concentrations of most trace elements $(<15 \mathrm{rel} \%)$. However, the abundances of $\mathrm{Cu}$ and $\mathrm{Ag}$ show a large scatter (33-120 and $10-147 \mathrm{rel} \%$, respectively). With the exception of $\mathrm{Cu}$ and $\mathrm{Ag}$, the overall composition of the melt inclusions is similar to the matrix glass (Table 1).

Although highly variable within a given set, the concentrations of $\mathrm{Cu}(2.76 \mathrm{ppm})$ and $\mathrm{Ag}(<0.12 \mathrm{ppm})$ are systematically low in the unheated inclusions (set A), and similar to those in the matrix glass. These low concentrations are in striking contrast with the $\mathrm{Cu}$ and $\mathrm{Ag}$ enrichment (1-3 orders of magnitude, up to $740 \mathrm{ppm} \mathrm{Cu}$ and up to $260 \mathrm{ppm} \mathrm{Ag}$ ) of the melt inclusions heated in the ceramic crucible (sets $\mathrm{B}$ and $\mathrm{C}$ ), and in the presence of $\mathrm{Cu}$ salt (set F). The significant variability in $\mathrm{Cu}$ and $\mathrm{Ag}$ and $\mathrm{Cu} / \mathrm{Ag}$ ratios was recorded among the melt inclusions in single quartz grain, and no clear correlation between the concentrations and the inclusions' size and position was found (Fig. 1). In other

TABLE 1. Average compositions (in ppm) of quartz-hosted melt inclusions and matrix glass from the rhyolite NZL27b (Taupo Volcanic Zone, New Zealand)

\begin{tabular}{|c|c|c|c|c|c|c|c|c|c|c|c|c|c|c|}
\hline \multirow[b]{2}{*}{$\mathrm{N}$} & \multirow[t]{2}{*}{$\begin{array}{c}\text { matrix glass } \\
\text { NZL27b }\end{array}$} & \multicolumn{2}{|c|}{$\begin{array}{c}\text { Set } \mathrm{A} \text {, } \\
\text { unheated }\end{array}$} & \multicolumn{2}{|c|}{$\begin{array}{c}\text { Set B, } \\
\text { heated } \\
\left(850^{\circ} \mathrm{C}, 24 \mathrm{~h}\right) \\
\end{array}$} & \multicolumn{2}{|c|}{$\begin{array}{c}\text { Set C, } \\
\text { heated } \\
\left(850^{\circ} \mathrm{C}, 120 \mathrm{~h}\right)\end{array}$} & \multicolumn{2}{|c|}{$\begin{array}{l}\text { Set } \mathrm{D} \text {, heated } \\
\text { in } \mathrm{Pt} \text { foil } \\
\left(850^{\circ} \mathrm{C}, 24 \mathrm{~h}\right)\end{array}$} & \multicolumn{2}{|c|}{$\begin{array}{c}\text { Set } \mathrm{E}, \sim 1 / 2 \text { set } \mathrm{B} \\
\text { mixed with } \mathrm{NaCl} \\
\text { and heated }\left(850^{\circ} \mathrm{C}, 24 \mathrm{~h}\right)\end{array}$} & \multicolumn{2}{|c|}{$\begin{array}{c}\text { Set } \mathrm{F} \text {, mixed } \\
\text { with } \mathrm{CuSO}_{4} \\
\left(850^{\circ} \mathrm{C}, 24 \mathrm{~h}\right)\end{array}$} & \multirow[t]{2}{*}{$\begin{array}{l}\text { Detect. } \\
\text { limit }\end{array}$} \\
\hline & & 26 & $\delta \%$ & 56 & $\delta \%$ & 10 & $\delta \%$ & 6 & $\delta \%$ & 8 & $\delta \%$ & 4 & $\delta \%$ & \\
\hline$\overline{\mathrm{CaO}}$ & 6400 & 5200 & 6 & 5600 & 8 & n.d. & & n.d. & & 5200 & 9 & 5200 & 4 & 180 \\
\hline $\mathrm{TiO} 2$ & 1250 & 1020 & 5 & 1050 & 12 & n.d. & & n.d. & & 1030 & 12 & 1070 & 8 & 0 \\
\hline $\mathrm{Cu}$ & 1.74 & 2.76 & 98 & 172 & 76 & 396 & 42 & 3.01 & 33 & $<0.665$ & 120 & 294 & 40 & 1.28 \\
\hline $\mathrm{Zn}$ & 42.1 & 45.3 & 9 & 46.0 & 18 & 42.0 & 9 & 42.7 & 7 & 46.8 & 15 & 40.3 & 2 & 0.427 \\
\hline $\mathrm{Rb}$ & 153 & 124 & 2 & 122 & 6 & 118 & 3 & n.d. & & 130 & 4 & 117 & 5 & 0.13 \\
\hline $\mathrm{Sr}$ & 35.1 & 27.2 & 11 & 28.5 & 11 & 30.0 & 7 & n.d. & & 26.0 & 22 & 25.8 & 6 & 0.029 \\
\hline$Y$ & 31.7 & 32.5 & 6 & 32.2 & 6 & 32.0 & 5 & 30.2 & 6 & 30.7 & 9 & 30.5 & 7 & 0.017 \\
\hline $\mathrm{Zr}$ & 88.0 & 93.8 & 8 & 91.9 & 12 & 92.3 & 9 & n.d. & & 87.2 & 11 & 86.5 & 9 & 0.037 \\
\hline $\mathrm{Nb}$ & 9.19 & 8.60 & 3 & 8.51 & 7 & 8.35 & 6 & n.d. & & 8.73 & 5 & 8.04 & 4 & 0.033 \\
\hline Mo & 1.88 & 1.67 & 22 & 1.68 & 25 & 1.74 & 12 & 1.75 & 10 & 2.00 & 30 & 1.65 & 29 & 0.688 \\
\hline $\mathrm{Ag}$ & $<0.045$ & $<0.123$ & 83 & 32 & 147 & 9.38 & 52 & 0.95 & 70 & 4.92 & 84 & 97.0 & 10 & 0.123 \\
\hline Sn & 3.16 & 2.73 & 10 & 2.54 & 9 & 2.39 & 13 & 2.57 & 8 & 2.92 & 14 & 2.36 & 6 & 0.124 \\
\hline $\mathrm{Ba}$ & 794 & 681 & 9 & 706 & 5 & 699 & 2 & n.d. & & 680 & 3 & 634 & 1 & 0.156 \\
\hline La & 30.3 & 27.6 & 8 & 27.3 & 5 & 27.7 & 3 & n.d. & & 26.8 & 4 & 24.9 & 1 & 0.016 \\
\hline $\mathrm{Ce}$ & 64.8 & 59.5 & 7 & 58.7 & 6 & 58.5 & 2 & n.d. & & 57.5 & 6 & 53.5 & 2 & 0.017 \\
\hline $\mathrm{Nd}$ & 24.4 & 25.0 & 4 & 24.8 & 8 & 24.7 & 6 & n.d. & & 23.3 & 9 & 22.7 & 7 & 0.071 \\
\hline $\mathrm{Sm}$ & 5.42 & 5.00 & 6 & 5.23 & 13 & 5.28 & 8 & n.d. & & 4.90 & 11 & 4.49 & 8 & 0.087 \\
\hline $\mathrm{Eu}$ & 0.44 & 0.475 & 18 & 0.443 & 23 & 0.455 & 17 & n.d. & & 0.383 & 20 & 0.394 & 19 & 0.024 \\
\hline $\mathrm{Gd}$ & 4.80 & 4.94 & 11 & 4.8 & 15 & 4.96 & 11 & n.d. & & 4.51 & 13 & 4.41 & 8 & 0.085 \\
\hline Dy & 5.18 & 5.56 & 8 & 5.31 & 11 & 5.40 & 7 & n.d. & & 5.13 & 13 & 5.04 & 11 & 0.047 \\
\hline $\mathrm{Er}$ & 3.35 & 3.51 & 9 & 3.32 & 8 & 3.45 & 7 & n.d. & & 3.29 & 9 & 3.11 & 5 & 0.036 \\
\hline $\mathrm{Yb}$ & 4.20 & 3.71 & 9 & 3.69 & 10 & 3.86 & 7 & n.d. & & 3.71 & 9 & 3.45 & 4 & 0.049 \\
\hline W & 1.91 & 1.63 & 7 & 1.58 & 16 & 1.52 & 5 & 1.67 & 9 & 1.87 & 12 & 1.48 & 16 & 0.074 \\
\hline $\mathrm{Pb}$ & 21.9 & 18.4 & 8 & 19.7 & 26 & 17.5 & 5 & 18.2 & 4 & 19.6 & 13 & 16.8 & 6 & 0.047 \\
\hline Th & 15.1 & 12.3 & 6 & 11.8 & 7 & 12.4 & 4 & n.d. & & 12.5 & 5 & 11.1 & 8 & 0.02 \\
\hline$U$ & 3.64 & 2.92 & 4 & 2.88 & 8 & 2.87 & 5 & n.d. & & 3.08 & 5 & 2.65 & 10 & 0.021 \\
\hline
\end{tabular}

Notes: Compositional variability is shown as $\delta \%=$ standard deviation/average, $100 \%$. Detection limits are given for analyses performed using $55 \mu \mathrm{m}$ beam. $\mathrm{N}=$ number of analyzed inclusions; n.d. = not analyzed. 
words, despite similar major and trace element compositions, and sometimes similar $\mathrm{Cu} / \mathrm{Ag}$, inclusions display a range of $\mathrm{Cu}$ and Ag contents even when they are located $<100 \mu \mathrm{m}$ of each other (Fig. 1). Due to this large scatter, no clear difference in the average $\mathrm{Cu}$ and $\mathrm{Ag}$ concentrations is observed between inclusions heated for 24 hours (set B) and 120 hours (set C), although it appears that $\mathrm{Cu}$ contents are higher in set $\mathrm{C}$.

Quartz-hosted melt inclusions which were isolated from both the ceramic crucible and the furnace environment by a platinum foil (set $\mathrm{D}$ ) have low $\mathrm{Cu}$ abundances (average $3 \mathrm{ppm}$ ), comparable with those in the matrix glass and unheated inclusions from set A (Table 1). Unlike $\mathrm{Cu}$, the Ag contents of set D melt inclusions are relatively high (average $1 \mathrm{ppm}$ ), but still considerably lower than in the sets $\mathrm{B}$ and $\mathrm{C}$ inclusions.

The melt inclusions that made up set $\mathrm{E}$ were originally in the set B grains, and thus we assume that they had the composi- tions of the set B inclusions before heating in the presence of $\mathrm{NaCl}$ powder. This experiment produced the compositions most depleted in $\mathrm{Cu}(<0.67 \mathrm{ppm})$, but still markedly enriched in $\mathrm{Ag}$ (4.9 ppm), if compared to the matrix glass and unheated melt inclusions.

The concentration of $\mathrm{Ag}$ analyzed in the quartz grains from all sets was always below the detection limit $(0.011 \mathrm{ppm})$. Whereas $\mathrm{Cu}$ abundances in quartz from the sets $\mathrm{A}, \mathrm{D}$ and $\mathrm{E}$ were also below the detection limit $(0.067 \mathrm{ppm})$, the sets $\mathrm{B}$ and $\mathrm{C}$ quartz showed distinctly high concentrations (0.29 and 0.28 ppm, respectively).

\section{DISCUSSION}

The compositional similarity between the matrix glass and quartz-hosted melt inclusions (Table 1) implies their close genetic relationships and argues for that the melt inclusions in this study
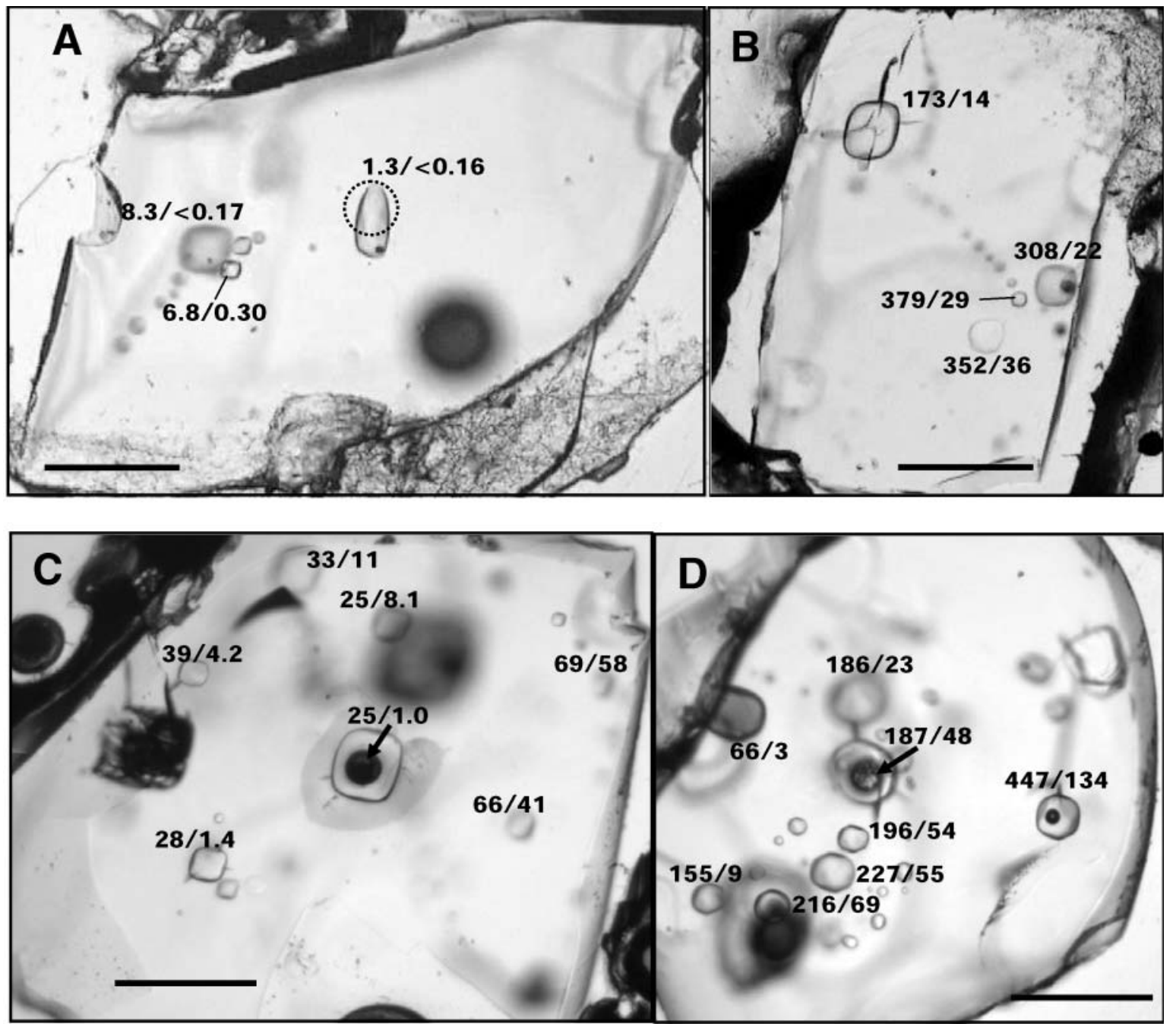

FigurE 1. Concentrations of copper and silver (labelled as $\mathbf{C u} / \mathbf{A g}$ ) in unheated (A) and heated (B-D) melt inclusions. Scale bars $200 \mu \mathrm{m}$. Arrows show laser ablation pits. Note that radial cracks around inclusions formed during grinding and polishing. 
are representative of the natural magma. Similar contents of most analyzed elements in unheated and heated melt inclusions (Table 1) suggest that host quartz phenocrysts were naturally quenched fast enough to prevent compositional changes related to crystallization on the walls of inclusions.

The main outcome of this study is a different behavior of $\mathrm{Cu}$ and $\mathrm{Ag}$ from other elements during experimental heating. In the experiments where host quartz was in direct contact with the heating "environment", we record elevated concentrations of $\mathrm{Cu}$ in quartz $(0.29 \mathrm{ppm})$, and abundances of both metals increase in the melt inclusions dramatically (Fig. 1B-D). The results of experiment with quartz grains wrapped in $0.05 \mathrm{~mm}$ platinum foil (set D) suggest that optically unidentified $\mathrm{Cu}-\mathrm{Ag}$ bearing phases (fluid, brine, sulfide, sulfate, etc) in the melt inclusions or host quartz cannot be the source of these metals. Moreover, the experiment in purposefully $\mathrm{Cu}$-rich environment (set F) shows that $\mathrm{Cu}$ mobility through the quartz host is the controlling factor of post-heating enrichment.

Diffusion of ions along dislocations, channels, twin boundaries or other structural defects in quartz (Kronenberg 1994 and references therein) can be responsible for the open system behavior of the melt inclusions, and in particular, for observed variability in the absolute abundances of $\mathrm{Cu}$ and $\mathrm{Ag}$, and often $\mathrm{Cu} / \mathrm{Ag}$ ratios, among melt inclusions in a single quartz grain (Fig. 1). However, diffusion into melt inclusions is noted for only two elements $(\mathrm{Cu}$ and $\mathrm{Ag})$ among $>30$ chemical elements measured (sets B and C), whereas diffusion out of melt inclusions is confidently recorded for $\mathrm{Cu}$ only (set $\mathrm{E}$ ). This means that the diffusion is determined by specific properties of the $\mathrm{Cu}$ and $\mathrm{Ag}$ ions rather than a control from structural characteristics of quartz. Thus, the phenomenal volatility of $\mathrm{Cu}$ and $\mathrm{Ag}$ can be accounted for when interpreting the results of other melt inclusion studies that showed metal enrichment in heated (remelted) melt inclusions compared to unheated inclusions from the same samples (Dietrich et al. 1999; Lowenstern et al. 1991).

Although Na behaved "inert" in our experiments, the heatingrelated gain of $\mathrm{Na}_{2} \mathrm{O}$ (from 4 to $7.7 \mathrm{wt} \%$ ) by quartz-hosted melt inclusions in the rhyodacitic pumices from Guadeloupe (Métrich 1988) implies that the uptake and/or loss of certain elements for each particular sample and/or experimental setup can be a problem. For example, in our experiments the "isolating" effect of the platinum foil, while strong for $\mathrm{Cu}$, is clearly diminished for $\mathrm{Ag}$ (set D), if the source of Ag enrichment in the melt inclusions was outside their host quartz. Thus, the geochemical applications of the melt inclusion data cannot be made without accessing all possible, naturally and experimentally induced, changes to the originally trapped compositions.

The process of $\mathrm{Cu}$ loss from melt inclusions (studied here and in other TVZ samples, our unpublished data), occurring in nature, is suggested by (1) exceptionally low $\mathrm{Cu}$ abundances in the unheated melt inclusions, (2) the results of the set E experiments. The latter clearly demonstrated that melt inclusions that are artificially enriched in $\mathrm{Cu}$, can be almost completely deprived of their $\mathrm{Cu}$ enrichment by a chloride-rich medium outside the host quartz.

Low $\mathrm{Cu}$ contents in the unheated melt inclusions ( $2.8 \mathrm{ppm})$ are unusual if compared with the concentrations of similar incompatible elements, for example $\mathrm{Yb}(3.7 \mathrm{ppm})$ or $\mathrm{Zn}(45.3$ $\mathrm{ppm})$. The $\mathrm{Cu} / \mathrm{Zn}(0.06)$ of the TVZ unheated melt inclusion is almost an order of magnitude lower than in a model depleted mantle (Salters and Stracke 2004) or the silicate Earth, "pyrolite" (McDonough and Sun 1995), but comparable with that in the matrix glass (0.04).

The presence of $\mathrm{Cu}$ (Fig. 2A) and $\mathrm{Cu}$ and $\mathrm{Ag}$ (Fig. 2B) in the shrinkage bubbles in the melt inclusions belonging to sets $\mathrm{A}$ and $\mathrm{B}$ is consistent with our record of their exceptional volatility. Strong Cu partitioning in the degassing fluid (Lowenstern 1993; Lowenstern et al. 1991) can account for $\mathrm{Cu}$ loss from the TVZ rhyolitic magma during eruption, and thus low $\mathrm{Cu}$ content in the matrix glass (Table 1). On the other hand, the melt trapped as melt inclusions appears to be undegassed (up to 7-8 wt $\% \mathrm{H}_{2} \mathrm{O}$ according the microprobe totals and direct measurements of $\mathrm{H}_{2} \mathrm{O}$ in other TVZ melt inclusions; our unpublished data and Dunbar and Kyle 1993). Thus the assumption of $\mathrm{Cu}$ loss from the melt via degassing prior to entrapment of the inclusions is not justified. The alternative explanation for unusually low $\mathrm{Cu}$ in the set A melt inclusions is that they lost their original $\mathrm{Cu}$ (at least 25 ppm according a model $\mathrm{Cu} / \mathrm{Zn}$ ratio of 0.55 (McDonough and Sun 1995; Salters and Stracke 2004) to the levels in the matrix glass during magma decompression and related degassing. In other words, the phenomenon of $\mathrm{Cu}$ diffusion out of melt inclusions, similar to that recorded in the set E experiments, suggests the possibility of re-equilibration of quartz-hosted melt inclusion with continuously $\mathrm{Cu}$-degassing magma during its ascent and eruption.

Our study demonstrates that (1) experiments that are not designed carefully can result in the open system behavior of quartz-hosted rhyolitic melt inclusions, and (2) natural processes
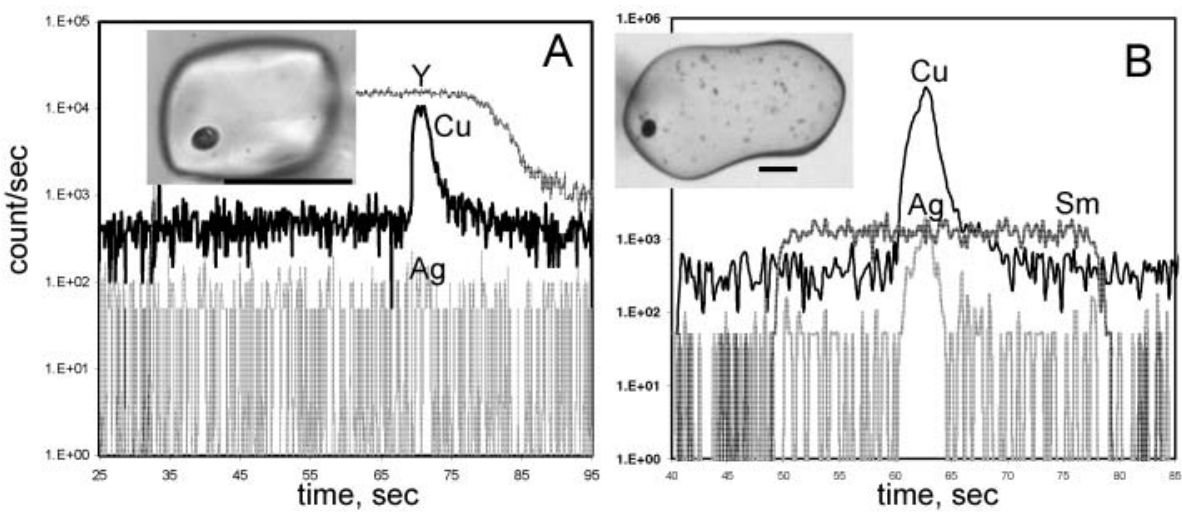

FIGURE 2. Signal intensities with time for copper and silver and selected lithophile elements recorded on the mass-spectrometer during analysis of unheated melt inclusions (set A, photos shown). Note increase in abundances of $\mathrm{Cu}$ (A) and $\mathrm{Cu}$ and $\mathrm{Ag}$ (B) that corresponds in time to the ablation of the shrinkage bubble. Scale bars $50 \mu \mathrm{m}$. 
(magma contamination, mixing and degassing) can change the composition of originally trapped melt by diffusion of certain elements in and out, to maintain equilibrium. Although we have recorded diffusion of $\mathrm{Cu}$ and $\mathrm{Ag}$ only, similar behavior of other elements in different samples cannot be excluded.

\section{ACKNOWLEDGMENTS}

We thank S. Allen for donating the sample NZL27b for this study, and P. Davidson, S. Storm and M. Kamenetsky for their assistance with sample preparation, measurements and helpful discussions. We are grateful to J. Lowenstern, N. Métrich, I. Veksler, S. Eggins, and T. Crawford for sharing their expertise and providing expert advice. The manuscript benefited from thoughtful reviews by R. Thomas and anonymous referee. This work was supported by an Australian Research Council Professorial Fellowship and Discovery Grant to V.S.K.

\section{REFERENCES CITED}

Anderson, A.T. (2003) An introduction to melt (glass \pm crystals) inclusions. In I Samson, A. Anderson, and D. Marshall, Eds., Fluid Inclusions: Analysis and Interpretation, Short Course Series, 32, p. 353-364. Mineralogical Association of Canada, Vancouver, BC.

Campos, E., Touret, J.L.R., Nikogosian, I., and Delgado, J. (2002) Overheated, $\mathrm{Cu}$-bearing magmas in the Zaldivar porphyry-Cu deposit, Northern Chile. Geodynamic consequences. Tectonophysics, 345, 229-251.

Cottrell, E., Spiegelman, M., and Langmuir, C.H. (2002) Consequences of diffusive reequilibration for the interpretation of melt inclusions. Geochemistry Geophysics Geosystems, 3, 10.1029/2001GC000205.

Danyushevsky, L.V., Della-Pasqua, F.N., and Sokolov, S. (2000) Re-equilibration of melt inclusions trapped by magnesian olivine phenocrysts from subduction-related magmas: petrological implications. Contributions to Mineralogy and Petrology, 138, 68-83.

Danyushevsky, L.V., McNeill, A.W., and Sobolev, A.V. (2002) Experimental and petrological studies of melt inclusions in phenocrysts from mantle-derived magmas: an overview of techniques, advantages and complications. Chemical Geology, 183, 5-24.

Davidson, P. and Kamenetsky, V.S. (2001) Immiscibility and continuous melt-fluid evolution within the Rio Blanco porphyry system, Chile: Evidence from inclusions in magmatic quartz. Economic Geology, 96, 1921-1929.

Dietrich, A., Lehmann, B., Wallianos, A., and Traxel, K. (1999) High copper and silver abundances in melt inclusions of Bolivian tin porphyry systems. In C.J. Stanley, et al., Ed. Proceedings of the Fifth biennial SGA Meeting and the Tenth Quadrennial IAGOD Symposium-Mineral Deposits: Processes to Processing, 1, p. 337-340. Balkema, Rotterdam, London, U.K

Dunbar, N.W. and Kyle, P. (1993) Lack of volatile gradient in the Taupo plinian-ignimbrite transition: evidence from melt inclusion analysis. American Mineralogist, 78, 612-618.

Frezzotti, M.L. (2001) Silicate-melt inclusions in magmatic rocks: applications to petrology. Lithos, 55, 273-299.
Gaetani, G.A. and Watson, E.B. (2000) Open system behavior of olivine-hosted melt inclusions. Earth and Planetary Science Letters, 183, $27-41$.

Kronenberg, A.K. (1994) Hydrogen speciation and chemical weakening of quartz. In P.J. Heaney, C.T. Prewitt, and G.V. Gibbs, Eds., Silica: physical behavior, geochemistry and materials applications, 29, p. 123-176. Reviews in Mineralogy, Mineralogical Society of America, Washington, D.C.

Longerich, H.P., Jackson, S.E., and Gunther, D. (1996) Laser ablation inductively coupled plasma mass spectrometric transient signal data acquisition and analytic concentration calculation. Journal of Analytical Atomic Spectrometry, 11, 899-904.

Lowenstern, J.B. (1993) Evidence for a copper-bearing fluid in magma erupted at the Valley of Ten Thousand Smokes, Alaska. Contributions to Mineralogy and Petrology, 114, 409-421.

- - - (1995) Applications of silicate-melt inclusions to the study of magmatic volatiles. In J.F.H. Thompson, Ed., Magmas, fluids, and ore deposits, Short Course Series, 23, p. 71-99. Mineralogical Association of Canada, Ottawa, Ontario.

Lowenstern, J.B., Mahood, G.A., Rivers, M.L., and Sutton, S.R. (1991) Evidence for extreme partitioning of copper into a magmatic vapor phase. Science, 252, 1405-1409.

McDonough, W.F. and Sun, S.-s. (1995) The composition of the Earth. Chemical Geology, 120, 223-253.

Métrich, N. (1988) Experimental evidence of selective Na enrichment of melt inclusions in quartz. Comptes Rendus de l'Academie des Sciences (Paris), 37, 1887-1892.

Nielsen, R.L., Michael, P.J., and Sours-Page, R. (1998) Chemical and physical indicators of compromised melt inclusions. Geochimica et Cosmochimica Acta, 62, 831-839.

Qin, Z., Lu, F. and Anderson, A.T., Jr. (1992) Diffusive reequilibration of melt and fluid inclusions. American Mineralogist, 77, 565-576.

Roedder, E. (1979) Origin and significance of magmatic inclusions. Bulletin de Mineralogie, 102, 487-510.

Salters, V.J.M. and Stracke, A. (2004) Composition of the depleted mantle. Geochemistry Geophysics Geosystems, 5, Q05004, doi:10.1029/2003GC000597.

Skirius, C.M., Peterson, J.W., and Anderson, A.T. (1990) Homogenizing rhyolitic glass inclusions from the Bishop Tuff. American Mineralogist, 75, 1381-1398.

Tait, S. (1992) Selective preservation of melt inclusions in igneous phenocrysts. American Mineralogist, 77, 146-155.

Thomas, R. (1994) Estimation of the viscosity and the water content of silicate melts from melt inclusion data. European Journal of Mineralogy, 6, 511-535.

Wilson, C.J.N., Houghton, B.F., McWilliams, M.O., Lanphere, M.A., Weaver, S.D., and Briggs, R.M. (1995) Volcanic and structural evolution of Taupo Volcanic Zone, New Zealand: a review. Journal of Volcanology and Geothermal Research, 68, 1-28.

MANUSCRIPT RECEIVED APRIL 21, 2005

MANUSCRIPT ACCEPTED JUNE 9, 2005

MANUSCRIPT HANDLED BY BRYAN CHAKOUMAKOS 